National Water-Quality Assessment Program

\title{
Protocols for Mapping and Characterizing Land Use/ Land Cover in Riparian Zones
}

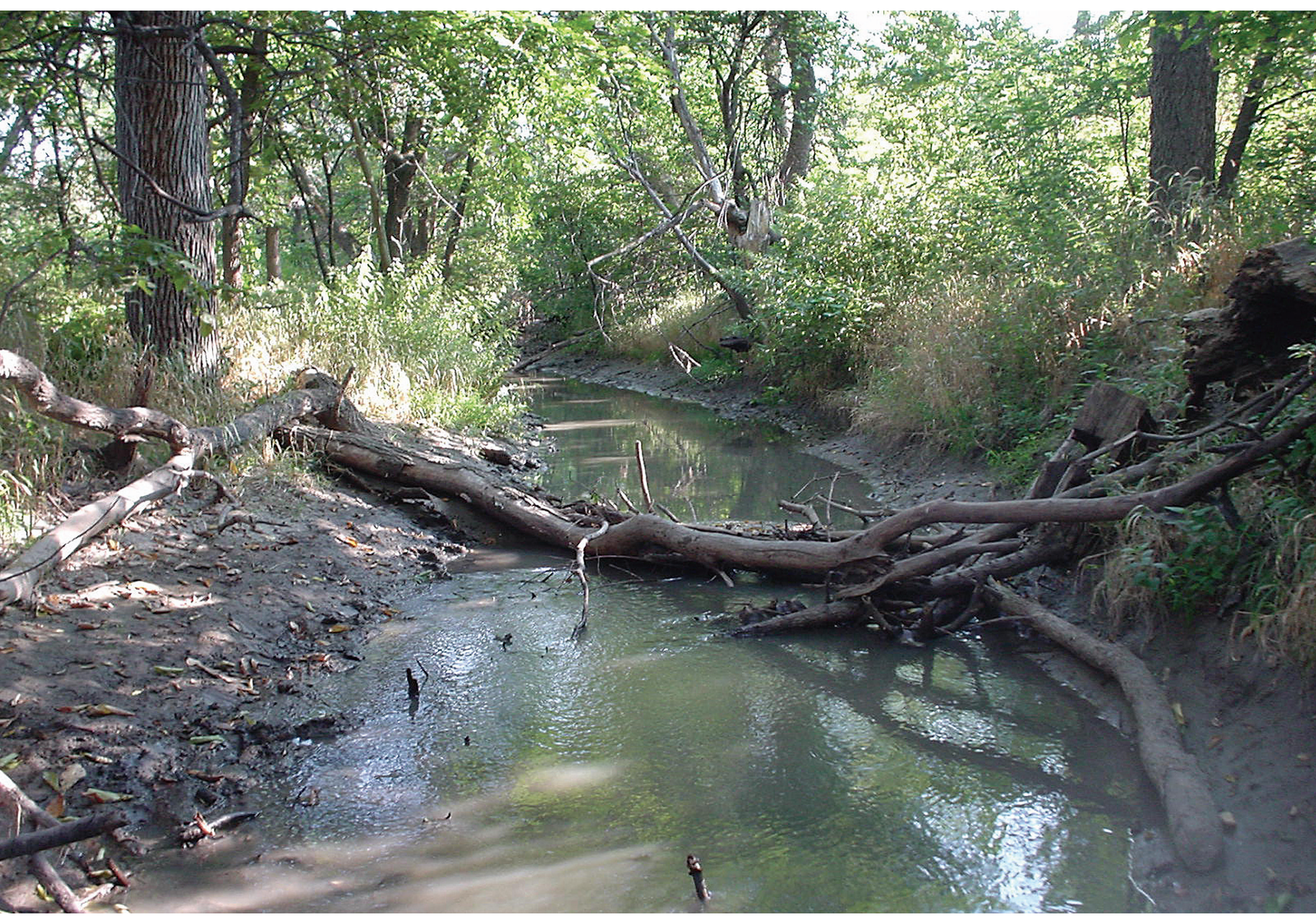

Open-File Report 2005-1302 
Cover photo: View of Elm Creek, 3.6 miles northwest of Elm Creek, Nebraska, August 6, 2003. 


\section{Protocols for Mapping and Characterizing Land Use/Land Cover in Riparian Zones}

By Michaela R. Johnson and Ronald B. Zelt

Prepared as part of the

NATIONAL WATER-QUALITY ASSESSMENT PROGRAM

Open-File Report 2005-1302 


\section{U.S. Department of the Interior \\ Gale A. Norton, Secretary}

\section{U.S. Geological Survey \\ P. Patrick Leahy, Acting Director}

U.S. Geological Survey, Reston, Virginia: 2005

For sale by U.S. Geological Survey, Information Services
Box 25286, Denver Federal Center
Denver, CO 80225
For more information about the USGS and its products:
Telephone: 1-888-ASK-USGS
World Wide Web: http://www.usgs.gov/

\footnotetext{
Any use of trade, product, or firm names in this publication is for descriptive purposes only and does not imply endorsement by the U.S. Government.

Although this report is in the public domain, permission must be secured from the individual copyright owners to reproduce any copyrighted materials contained within this report.

Suggested citation:

Johnson, M.R., and Zelt, R.B., 2005, Protocols for Mapping and Characterizing Land Use/Land Cover in Riparian Zones: U.S. Geological Survey Open-File Report 2005-1302, 22 p.
} 


\section{FOREWORD}

The U.S. Geological Survey (USGS) is committed to providing the Nation with accurate and timely scientific information that helps enhance and protect the overall quality of life and that facilitates effective management of water, biological, energy, and mineral resources (http://www.usgs.gov/. Information on the quality of the Nation's water resources is critical to assuring the long-term availability of water that is safe for drinking and recreation and suitable for industry, irrigation, and habitat for fish and wildlife. Population growth and increasing demands for multiple water uses make water availability, now measured in terms of quantity and quality, even more essential to the long-term sustainability of our communities and ecosystems.

The USGS implemented the National Water-Quality Assessment (NAWQA) Program in 1991 to support national, regional, and local information needs and decisions related to water-quality management and policy (http://water.usgs.gov/nawqa). Shaped by and coordinated with ongoing efforts of other Federal, State, and local agencies, the NAWQA Program is designed to answer: What is the condition of our Nation's streams and ground water? How are the conditions changing over time? How do natural features and human activities affect the quality of streams and ground water, and where are those effects most pronounced? By combining information on water chemistry, physical characteristics, stream habitat, and aquatic life, the NAWQA Program aims to provide science-based insights for current and emerging water issues and priorities.

From 1991-2001, the NAWQA Program completed interdisciplinary assessments in 51 of the Nation's major river basins and aquifer systems, referred to as Study Units (http://water.usgs.gov/nawqa/ studyu.html. Baseline conditions were established for comparison to future assessments, and long-term monitoring was initiated in many of the basins. During the next decade, 42 of the 51 Study Units will be reassessed so that 10 years of comparable monitoring data will be available to determine trends at many of the Nation's streams and aquifers. The next 10 years of study also will fill in critical gaps in characterizing water-quality conditions, enhance understanding of factors that affect water quality, and establish links between sources of contaminants, the transport of those contaminants through the hydrologic system, and the potential effects of contaminants on humans and aquatic ecosystems.

The USGS aims to disseminate credible, timely, and relevant science information to inform practical and effective water-resource management and strategies that protect and restore water quality. We hope this NAWQA publication will provide you with insights and information to meet your needs, and will foster increased citizen awareness and involvement in the protection and restoration of our Nation's waters.

The USGS recognizes that a national assessment by a single program cannot address all waterresource issues of interest. External coordination at all levels is critical for a fully integrated understanding of watersheds and for cost-effective management, regulation, and conservation of our Nation's water resources. The NAWQA Program, therefore, depends on advice and information from other agencies-Federal, State, interstate, Tribal, and local—as well as nongovernmental organizations, industry, academia, and other stakeholder groups. Your assistance and suggestions are greatly appreciated.

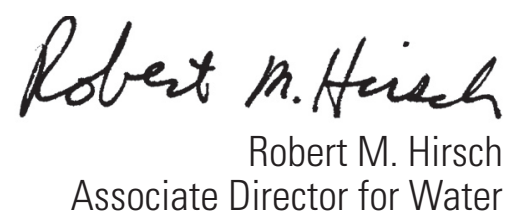




\section{Contents}

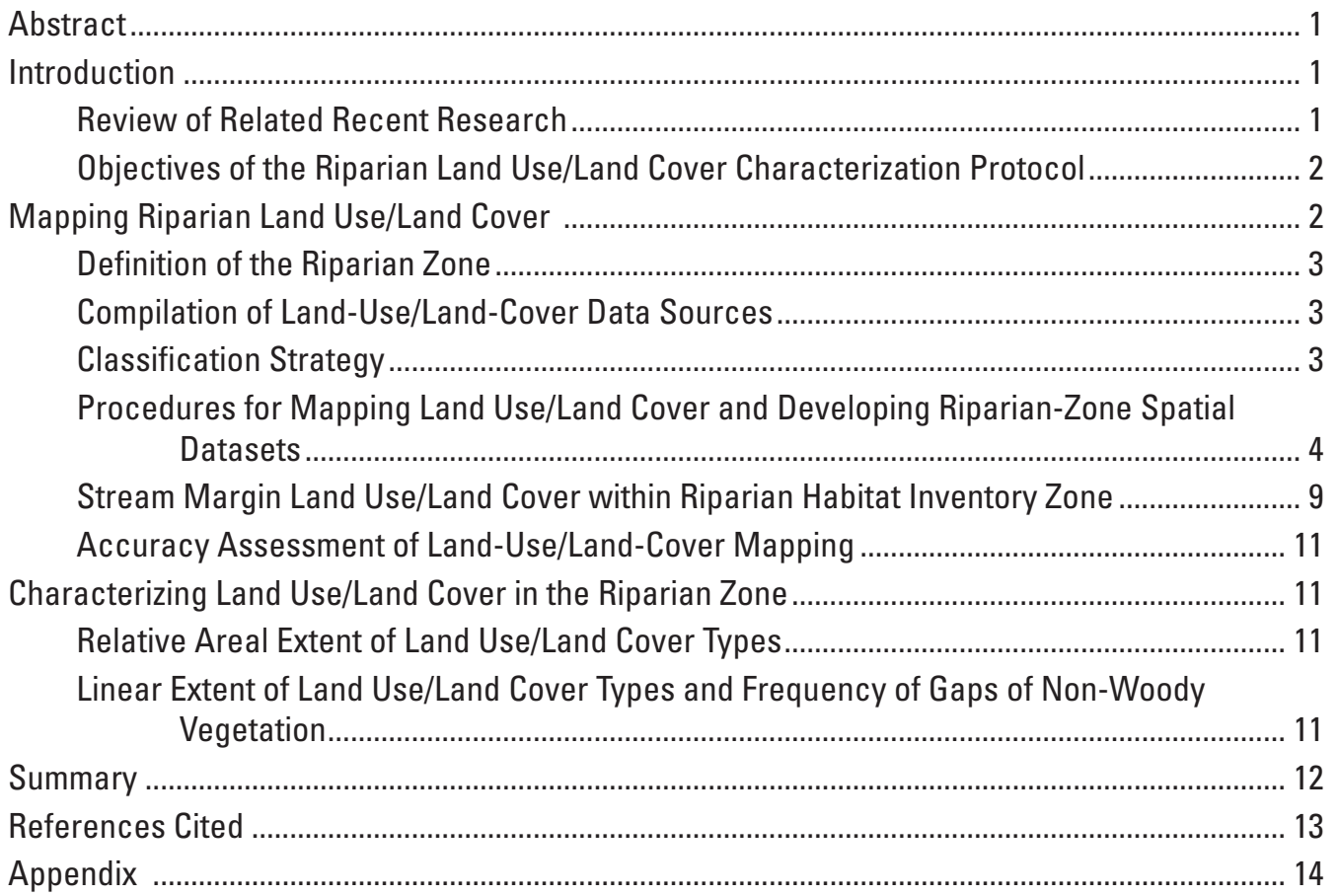

\section{Figures}

1-7. Maps showing:

1. Example delineation of the stream centerline for Mud Creek near Mason City, Nebraska.

2. Example of extension of drainage basin for Prairie Creek near Silver Creek, Nebraska

3. Addition of land-use/land-cover (LULC) map unit boundaries to subdivide the LULC_S250 coverage into LULC categories for Mud Creek near Mason City, Nebraska

4. Mapped and classified land use/land cover within the riparian zone along a stream segment for Mud Creek near Mason City, Nebraska.

5. Stream margin lines are generated by buffering the blue centerline and deleting the "end caps" leaving only the red transect lines.

6. Results of sampling the land cover along the longitudinal bisectors of the NAWOA-defined riparian habitat inventory zone of $30 \mathrm{~m}$ beyond each stream bank.

7. Location of the 28 sampling sites in the CNBR Study Unit. 


\section{Tables}

1. Land-use and land-cover classification system. …….................................................... 3

2. Relative areal extent of each land use/land cover class............................................... 12

3. Linear extent of each land use/land cover class along longitudinal transects of stream segments and reaches.

\section{Conversion Factors and Datum}

\begin{tabular}{lcl}
\hline Multiply & By & To obtain \\
\hline & Length & \\
meter $(\mathrm{m})$ & 3.281 & foot $(\mathrm{ft})$ \\
kilometer $(\mathrm{km})$ & 0.6214 & mile $(\mathrm{mi})$ \\
\hline & Area & \\
\hline square meter $\left(\mathrm{m}^{2}\right)$ & 0.0002471 & acre \\
square kilometer $\left(\mathrm{km}^{2}\right)$ & 0.3861 & square mile $\left(\mathrm{mi}^{2}\right)$ \\
\hline
\end{tabular}

Horizontal coordinate information is referenced to the North American Datum of 1983 (NAD 83).

\section{Abbreviations and Acronyms (additional information noted in parentheses)}

$\begin{array}{ll}\text { AML } & \text { ARC Macro Language } \\ \text { BioTDB } & \text { Biological Transactions Database } \\ \text { CNBR } & \text { Central Nebraska Basins (study unit) } \\ \text { DO00 } & \text { Digital orthophoto quarter-quadrangle } \\ \text { GIS } & \text { Geographic information system } \\ \text { GPS } & \text { Global Positioning System } \\ \text { IBI } & \text { Index of biotic integrity } \\ \text { LULC } & \text { Land use/land cover } \\ \text { NAPP } & \text { National Aerial Photography Program } \\ \text { NLCD } & \text { National Land Cover Dataset } \\ \text { NAWQA } & \text { National Water-Quality Assessment (program) } \\ \text { TM } & \text { Thematic Mapper (data) } \\ \text { USGS } & \text { U.S. Geological Survey }\end{array}$





\title{
Protocols for Mapping and Characterizing Land Use/Land Cover in Riparian Zones
}

\author{
By Michaela R. Johnson and Ronald B. Zelt
}

\begin{abstract}
Protocols for mapping and characterizing land-use/landcover (LULC) features in the riparian zone are presented in this report. The protocols are documented for use by the U.S. Geological Survey's National Water-Quality Assessment (NAWQA) Program. At each of the study sites in NAWQA's Central Nebraska Basins (CNBR) Study Unit, LULC features were examined along each stream segment, which was the length of the logarithm of the basin area within a 250-meter (m) maximum buffer width. Delineation of LULC map units along buffered stream segments was conducted using on-screen digitizing of riparian LULC classes from the digital orthophoto quarter-quadrangles. The riparian LULC units were mapped using a classification strategy consisting of nine classes. The areal extents of LULC types along the segment- and reach-buffered streams were determined. Longitudinal riparian transect lines were generated, offset from selected streams in the study area, then partitioned into the underlying LULC types to obtain the relative linear extent of each LULC type and frequency of gaps in woodland areas within the riparian zone. The produced LULC data filled in the spatial-scale gap between the 30-m National Land Cover Dataset (NLCD) data and the reach-level habitat assessment data. The benefits of this approach are a consistent methodology and a more ecologically relevant scale of data provided than had been available.
\end{abstract}

\section{Introduction}

Characterization of riparian systems is critical to a comprehensive understanding of nutrient enrichment effects on stream ecosystems because riparian functions provide an important ecological connection between surrounding landuse activities and nutrient dynamics in small-to-medium-sized streams. Riparian zones influence the level of nutrient enrichment of stream ecosystems in various ways, including:

(1) filtering or uptake of nutrients, sediments, and some organic chemicals from surface runoff and subsurface flows, (2) providing shade for streams thereby reducing light penetration, moderating water temperatures, and decreasing primary production, (3) providing an important source of energy through particulate organic matter input, (4) contributing large woody debris that creates habitat substrate and cover, (5) stabilizing stream banks through root strength and hydraulic shielding, and (6) extending the duration of stream-flood plain interaction by increasing hydraulic resistance (Brinson and others, 1981, Gregory and others, 1991, Naiman, 1992, Malanson, 1993, Schuft and others, 1999).

The purpose of this report is to document the protocols that are being used for mapping and characterizing riparian zones of streams at both the segment and reach scales. Specifically, this report describes a method for filling in a data gap of spatial scale in woodland LULC between the land-cover data available from the 30-meter (m) 1990s National Land Cover Dataset (NLCD) (Vogelmann and others, 2001) and the reach-level data available from the prescribed National Water Quality Assessment (NAWQA) habitat assessment. During the reach-level habitat assessment, dominant LULC within 30-m from the top of the each stream bank is observed at 11 evenlyspaced transects (Fitzpatrick and others, 1998). The method documented in this protocol is cost-effective, and the resulting riparian LULC includes those data at the ecologically important scale of stream segments.

The protocols described in this report are used to support the U.S. Geological Survey's (USGS) National Water-Quality Assessment (NAWQA) Program. NAWQA uses a combined physical, chemical, and biological approach to assess the Nation's water quality in 42 major river-basin and aquifer systems. Habitat conditions are evaluated using a modified hierarchical system proposed by Frissell and others (1986) at four scales — basin, segment, reach and microhabitat (Fitzpatrick and others, 1998). Land-use/land-cover (LULC) data, primarily woody vegetation, produced following the methods in this report are being used in evaluating nutrient-enrichment conditions at the segment and reach scales for a subset of the NAWQA major-river basins.

\section{Review of Related Recent Research}

Recent literature reviews of relations among riparian habitat, nutrients, fish and algal communities, and macroinvertebrates can be found in Schuft and others (1999), Fitzpatrick and others (2001), and Lattin and others (2004). 
Schuft and others (1999) examined sampling methods and landscape metrics to characterize the riparian stream networks. Longitudinal and lateral extents along streams of land-cover types interpreted from aerial photography were examined for incrementally wider buffers out to a maximum distance of $300 \mathrm{~m}$ from the stream using a process called incremental banding. The use of this technique allowed for the determination of landscape metrics, such as stream margin habitat, riparian width, and number of gaps of non-woody vegetation for use in examining relations with aquatic biota.

Fitzpatrick and others (2001) examined environmental characteristics in relation to stream conditions at multiple scales-watershed, segment, and reach scales. LULC information was obtained from 30-m Landsat 5 Thematic Mapper (TM) data for the watershed scale. The variable, "riparian width," for the segment and reach scales was measured from aerial photography. They found the index of biotic integrity (IBI) for fish was related more to adjacent land cover in a 50-m buffer along the entire stream network rather than to LULC at the watershed scale. The IBI is a numerical measure indicating the health of the fish community in a given river and is derived from a variety of observed conditions. LULC data were not available at the segment and reach scales. Metrics for invertebrates and algae were not strongly correlated with watershed LULC, but were correlated with riparian width at the segment and reach scales.

Different sources of remotely sensed imagery, that is, aerial photography compared to satellite imagery, may yield varying estimates of stream ecological condition, as examined at varying longitudinal and lateral scales by Lattin and others (2004). The ecological indicators considered in their study were fish IBI and nitrate concentration. They used a range of longitudinal and lateral scales to quantify LULC. Fish IBI correlated best with the narrowest lateral and longest longitudinal vegetation metric. Nitrate was best related to cropland classes for the widest lateral and longest longitudinal scale. Aerial photography and satellite imagery performed equally well, with each having respective advantages in terms of spatial resolution and ability to automate interpretation.

Sponseller and others (2001) examined the influence of spatial scale and land use classified from 30-m Landsat TM data on stream macroinvertebrate communities. They examined five spatial scales - the entire watershed, the riparian system for the whole stream network, and the riparian corridor for three segment lengths of 200, 1,000, and 2,000 m upstream from the sampling reach, each with a lateral extent of $30 \mathrm{~m}$. Water chemistry was most strongly related to LULC patterns for the entire watershed. Stream temperature and substrate were associated with LULC for the whole stream network and for the three segment lengths. The macroinvertebrate communities were most influenced by LULC at the most local scale, the 200-m segment riparian corridor.

Previous studies thus have documented that delineation of the areal extent of riparian woodland can aid understanding of the relative importance of its influences on different streams, thereby facilitating comparisons. Other land uses in the ripar- ian zone also can be documented efficiently during the mapping of the riparian woodland, and often have been correlated with nutrient levels or biotic conditions in the streams. The existing literature also indicates that no standard exists for stream segment length or stream-side buffer width that is best representative of the segment-level LULC influences on nutrient enrichment of streams.

\section{Objectives of the Riparian Land Use/Land Cover Characterization Protocol}

This report describes a protocol for characterizing riparian LULC at both the reach and segment scales. The objectives of the protocol are:

- To quantify the relative linear extent (percentage of cover) of riparian habitats (as represented by LULC) at the reach scale along the stream corridor and the areal extent of the reach buffered at 25 and $50 \mathrm{~m}$ from the stream into the adjacent landscape.

- To quantify the relative linear extent of riparian habitats at the segment scale along the stream corridor and the areal extent of the segment buffered at 50, 100, 150, and $250 \mathrm{~m}$ from the stream into the adjacent landscape. The length of stream segment examined is the base10 logarithm of the basin area in square kilometers (Sorenson and others, 1999; Stauffer and others, 2000).

- To quantify the frequency of gaps between riparian woodland map units (count per kilometer length of stream) along the stream, at both the reach and segment scales. The frequency and average length of gaps between riparian woodland map units are target characteristics of interest.

The following protocol standardizes the approach to achieve these objectives so that resulting data are comparable among different sites and across different time periods. The methodology is presented in two major sections: (1) mapping riparian LULC; and (2) characterizing LULC in the riparian zone.

\section{Mapping Riparian Land Use/Land Cover}

The protocol for mapping riparian LULC is described in this section of the report. This protocol was used by the Central Nebraska Basins (CNBR) Study Unit staff as an example. Results from the CNBR are presented herein for illustration and clarification. 


\section{Definition of the Riparian Zone}

The study segment length is defined using the orthoimagery to delineate the channel centerline upstream from the sampling site for a distance, $x$, in kilometers, which is the logarithm of the basin area $\left(A_{d}\right)$ in square kilometers,

$$
x=\log _{10}\left(A_{d}\right)
$$

The benefit of this approach is standardizing the determination of the area of influence (Sorenson and others, 1999; Stauffer and others, 2000). The units do not work out from the formula (square kilometers to kilometers), but the purpose is to derive a segment length value to standardize segment length in relation to basin area. The segment-level riparian zone will be characterized and defined by the maximum buffer width, $250 \mathrm{~m}$, extending outward from the stream centerline.

The study reach for each site is derived independently from the segment, and may have a variable length, following the guidance in Fitzpatrick and others (1998). The reach-level riparian zone is again operationally defined by the maximum buffer width, $250 \mathrm{~m}$, extending outward from the stream centerline.

\section{Compilation of Land-Use/Land-Cover Data Sources}

The first step in compiling LULC data is to obtain the best available orthoimagery (1:12,000-scale or greater) for the selected study sites. Digital orthophoto quarter-quadrangles (DOQQs) are developed from 1:40,000-scale National Aerial
Photography Program (NAPP) photographs, rectified to a horizontal accuracy that is equivalent to the National Map Accuracy Standard for 1:12,000-scale with a square cell size (pixel) of 1 m (U.S. Geological Survey, 1998). If the DOQQs are not available for a study area, these may need to be purchased. The time period of the source photograph is important for vegetation classification. The leaf-on time period for the source imagery is ideal for vegetation mapping (Lillesand and Kieffer, 1994).

\section{Classification Strategy}

Delineation of LULC map units can be performed using on-screen digitizing of boundaries between contrasting riparian land-cover classes that are distinguishable in the orthoimagery. The minimum mapping area for a land-cover unit is $60 \mathrm{~m}^{2}$. Imagery may be used in its native projection. The process of LULC interpretation from aerial photography requires the interpreter to identify each class of LULC, to distinguish the boundary between adjacent identifiable map units, and to delineate the discrete areal units throughout the riparian zone. During the interpretation process, it is suggested to start with the most easily distinguishable or highly contrasting parcels (Lillesand and Kieffer, 1994).

The riparian LULC units are mapped using a customized LULC classification system adapted for use for characterizing riparian zones (table 1). This classification system is a modified version of the classification strategy by Anderson and others (1976).

Table 1. Land-use and land-cover classification system.

[Modified from Anderson and others 1976; LU_CODE, land-use code used in digital data and tables; LULC, land use and land cover]

\begin{tabular}{cll}
\hline LU_CODE & \multicolumn{1}{c}{ LULC Class } & \multicolumn{1}{c}{ Explanation } \\
\hline B & Barren land & Bare soil, sand, gravel deposit, rock outcrop \\
C & Cropland & Row crops, small grains, alfalfa, or other herbaceous crops \\
F & Farmstead & Farm dwelling, outbuildings, barnyards, livestock yards or pens \\
G & Grassland & Grass, pasture or herbaceous rangeland \\
O & Open water & Water bodies including ponds, lakes, streams, and canals \\
S & Shrubland & Shrubs, where able to distinguish \\
U & Urban/built-up land & Urban residential, commercial, transportation or industrial land covers \\
W & Wetland & Both herbaceous and wooded wetlands \\
WV & Woody vegetation & Trees, shrubs, brushy rangeland (includes orchards and vineyards) \\
\hline
\end{tabular}


The classification system by Anderson and others (1976) has been adopted to represent what could be most consistently classified among drainage basins across contrasting environmental settings. The shrubland and woodland categories have been merged to become woody vegetation for this report. Although woodland areas also may contain understory shrubs and grasses, as well as shrubland, these two land cover types often are not readily distinguishable by visual interpretation of an aerial photograph. Where shrubland is distinguishable from woodland, these land cover types should be mapped separately with shrubland coded, "S." Discrimination between pasture and grasslands is not consistently possible from DOQQ imagery either. The aggregated grassland category includes managed or unmanaged grassland, rangeland, and pasture settings.

\section{Procedures for Mapping Land Use/Land Cover and Developing Riparian-Zone Spatial Datasets}

The first step in mapping LULC and developing riparian-zone spatial datasets is to identify and compile the set of DOQQ necessary for delineating the segment and its associated riparian LULC for each study site. This task is facilitated by using Geographic Information System (GIS) spatial proximity-analysis processing to create a buffer area having a 4,000-m radius around each study site. For consistency, name the sites-buffered output coverage, GET_DOQQ. Use these areas to overlay the sites-buffered coverage on a DOQQ index coverage to select the quadrangles needed and generate a list of DOQQ by quadrangle name. Obtain the indicated DOQQ images and add the imagery into a GIS database.

The second step is to delineate the centerline of the stream using orthoimagery as the base (fig. 1). Begin by creating a new (empty) coverage, CENTERLINE, and digitize the

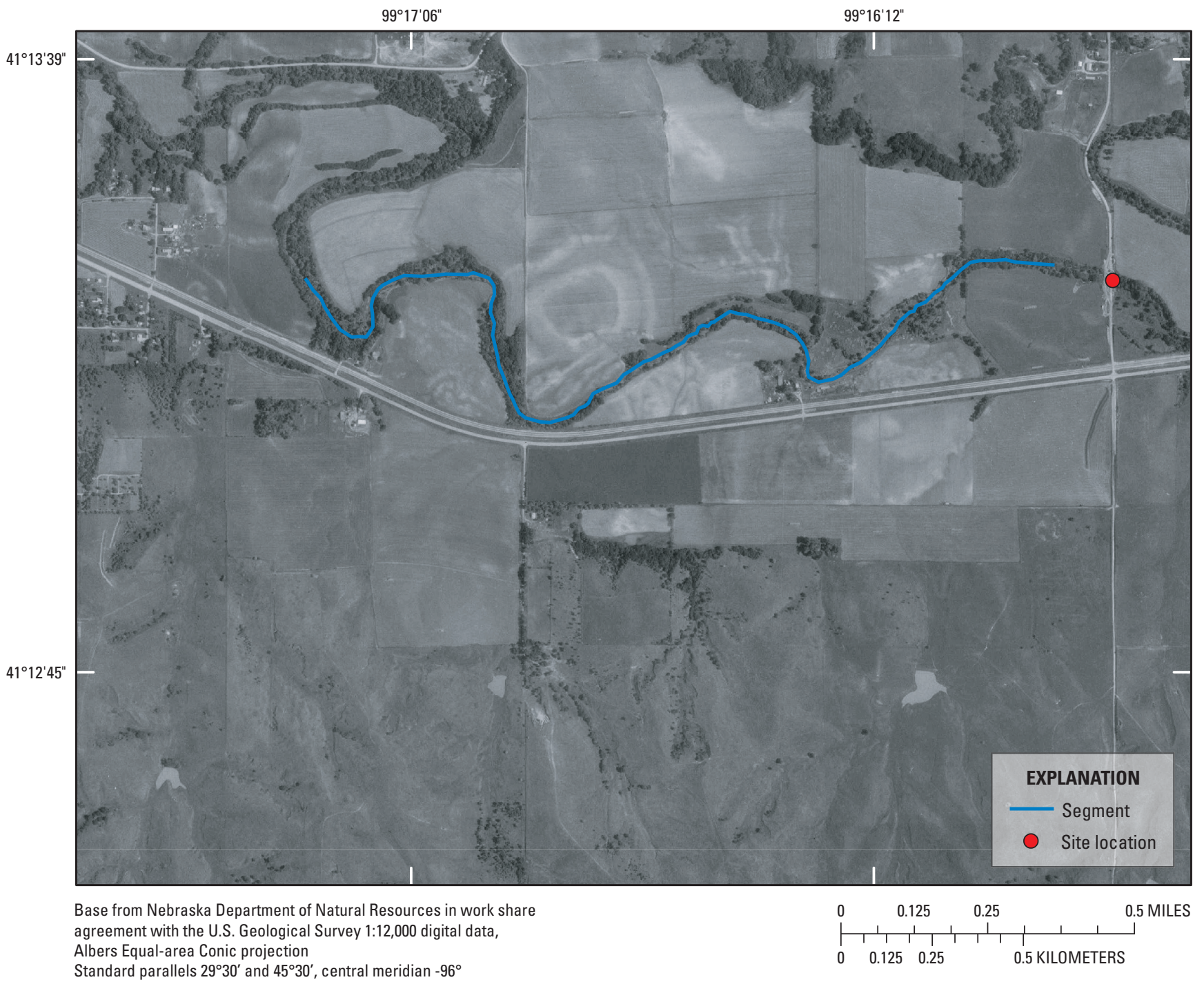

Figure 1. Example delineation of the stream centerline for Mud Creek near Mason City, Nebraska. 
stream centerline to a sufficient distance upstream from the study site, or to the maximum headward extent of the channel. The starting point of the centerline should be the downstream boundary of the reach. The starting point may be recorded as the actual geographic coordinates for the boundary or as the distance upstream from a reference location, such as a bridge crossing. The downstream boundary of the reach can be obtained from the NAWQA Biological Transactions Database (BioTDB). In most cases, digitizing a channel length of 3.5 $\mathrm{km}$ will be more than sufficient. In situations with braided channels or islands in the channel, follow the perennial channel with greatest flow. If the channels are approximately equal or impossible to distinguish, digitize down the center of the channel through the island. Add a field/column (STAID) to the CENTERLINE attribute table, and assign the USGS station identifier. Using the same CENTERLINE attribute table, add the fields representing basin area (BSNAREA) and reach length $\left(R \_L E N G T H\right)$. Basin area can be obtained from pre-existing drainage basin boundary coverages, if available. Otherwise, the upstream basins will need to be delineated. The value of $R \_L E N G T H$ is the measured reach length from onsite habitat assessments. Add another new field, LOGAREA, and set the widths, type, and decimal places as floating: 4, 12, F, 3. Calculate LOGAREA as the base-10 logarithm of the basin area:

$$
\text { LOGAREA }=\log (B S N A R E A)
$$

The third step is to trim the segment and reach lines to their appropriate lengths using the following procedure. First, add the attributes $S \_S H O R T$ and $R \_S H O R T$ to the CENTERLINE coverage. These attributes should be specified the same as LOGAREA with the widths, type, and decimal places as floating: 4, 12, F, 3. Calculate segment length excess $\left(S_{-}\right.$ $S H O R T$, in meters) as the digitized length minus the value of LOGAREA converted to meters; that is, S_SHORT $=$ LENGTH - $(L O G A R E A * 1,000)$. To calculate reach length excess ( $R \_S H O R T$, in meters), subtract the value of $R \_L E N G T H$ from LENGTH. These attributes provide the distance by which each individual segment and reach must be shortened to the correct length. Each of the streams needs to be a single arc. Make two copies of the CENTERLINE coverage, naming one, SEGMENT, and the other, REACH. Use the Arc Macro Language (AML) program, ashorten.aml (Banerjee, 2002) (see appendix for source code), to automatically trim the digitized line work in the segment and reach coverages using the values stored in $S \_S H O R T$ and $R \_S H O R T$, respectively. This AML needs to be placed in the archome/arcexe*/atool/arcedit directory. Archome is the parent folder of the ArcGIS software and $*$ represents the numerical version of the software. Then ashorten can be used at the ArcEdit command prompt by selecting the arc and entering the distance to shorten. If the ArcMap component of the ArcGIS environment is being used, the menu option, split, when in edit mode will perform the same task as ashorten.aml in the ArcEdit component.

The fourth step is to create the boundary for the riparian zone and digitize the distinguishable LULC units within that boundary. Buffer the SEGMENT centerlines, specifying the buffer width as $250 \mathrm{~m}$ on each side, and create RIPN_ZONE as the stream-buffered boundary or riparian-zone boundary output dataset. Clip RIPN_ZONE to the drainage basin boundary. If the beginning of the segment extends beyond the basin boundary or begins upstream from the basin boundary, then a new clip coverage should be created, RIPN_CLIP. The drainage basin should be extended or trimmed to the bottom of the segment, which is the downstream end of the reach boundary (fig. 2). Use the coverage, RIPN_CLIP, to clip RIPN_ZONE to the drainage basin boundary to create LULC_S250. Subdivide each polygon in LULC_S250 by adding LULC mapunit boundaries as needed to classify LULC in each riparian polygon into one of the nine categories, similar to figure 3 . The minimum area digitized should be $60 \mathrm{~m}^{2}$. This roughly corresponds to a circle with a diameter of $9 \mathrm{~m}(30 \mathrm{ft})$. Create label points (using the createlabels function) and update (build function or use the clean function if necessary) polygon topology for the LULC_S250 coverage.

The fifth step is to assign land-cover class codes to each polygon in the newly created riparian-zone coverage, LULC_S250. Add an attribute column, $L U \_C O D E$, to the coverage, LULC_S250, defined as character type with an item width of 2. Populate the $L U_{-} C O D E$ field with one of the nine alphabetic values (table 1). An example of a completed riparian-zone LULC map is the one for Mud Creek near Mason City, Nebraska (fig. 4).

After mapping the LULC for the full riparian zone extent, the sixth step is to create other coverages corresponding to each unique buffer width for the segment and reach scales. To create new segment-buffered boundary coverages, perform a proximity analysis (buffer function) of the SEGMENT coverage with specified distances of $50 \mathrm{~m}$ (SEGBUF50), $100 \mathrm{~m}$ (SEGBUF100), and $150 \mathrm{~m}$ (SEGBUF150). To create segmentbuffered LULC coverages, perform an overlay analysis (clip function) of the riparian-zone LULC coverage (LULC_S250) using the SEGBUF50, SEGBUF100, and SEGBUF150 coverages to create LULC_S50, LULC_S100 and LULC_S150, respectively. Use the buffer function to create the reach-buffered boundary coverages REACHBUF25 and REACHBUF50 by specifying buffering distances of 25 and $50 \mathrm{~m}$, respectively. Create corresponding reach-level LULC data sets, LULC_R25 and LULC_R50, by using the clip function to clip the riparianzone LULC coverage, LULC_S250, with the reach-buffered boundary coverages, REACHBUF25 and REACHBUF50.

Other buffer distances can be specified to generate additional segment or reach LULC coverages corresponding to differing distance ranges from the stream. Because each resulting LULC overlay yields slightly different information in terms of the relative extent of each LULC category within the riparian zone at the segment and reach levels, it is important to document which data are reported. Because the characteristics of sites will be compared within and across study units, riparian zone characteristics derived using buffer distances other than those specified by the protocol should not be used. 


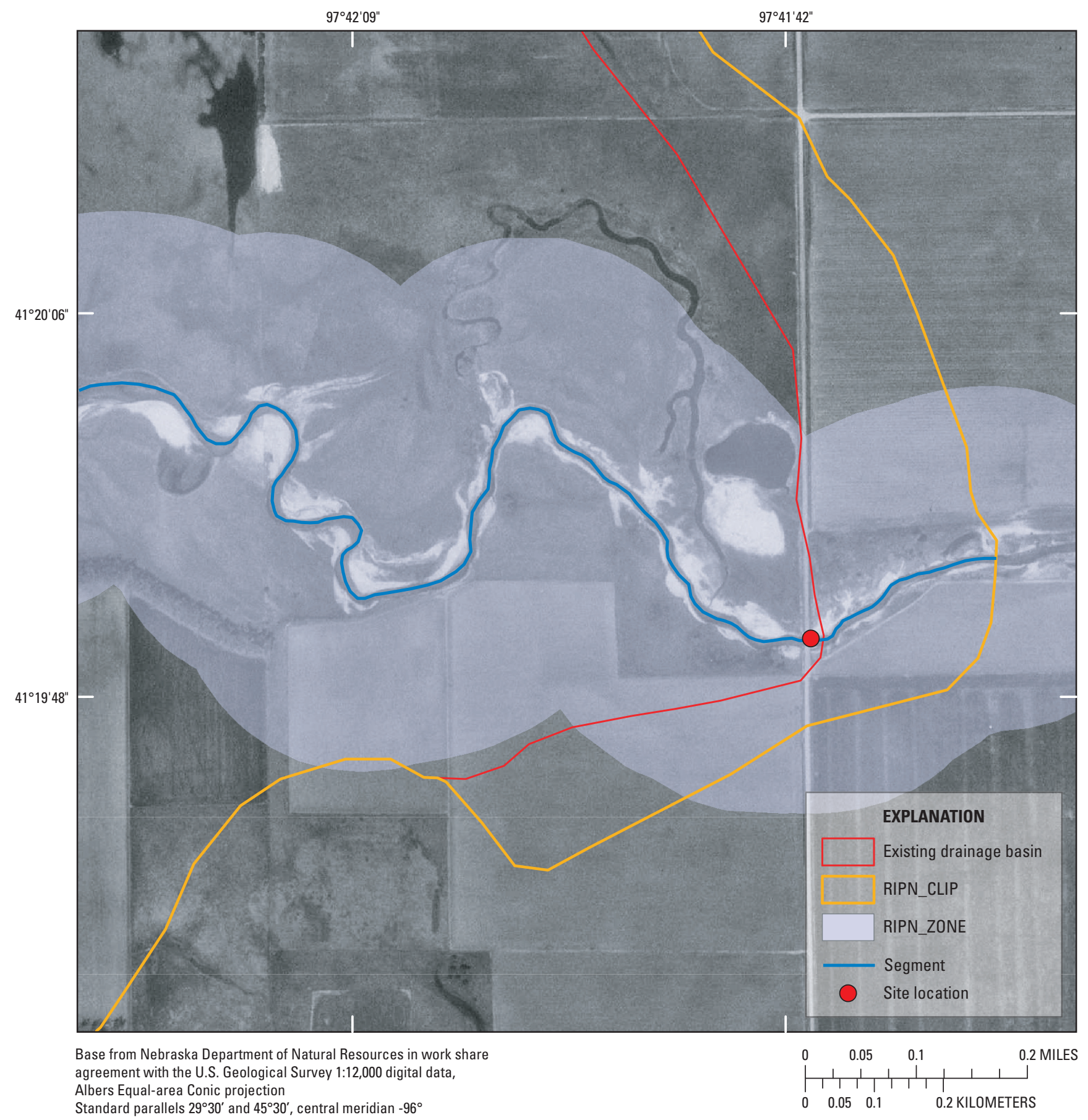

Figure 2. Example of extension of drainage basin for Prairie Creek near Silver Creek, Nebraska. 


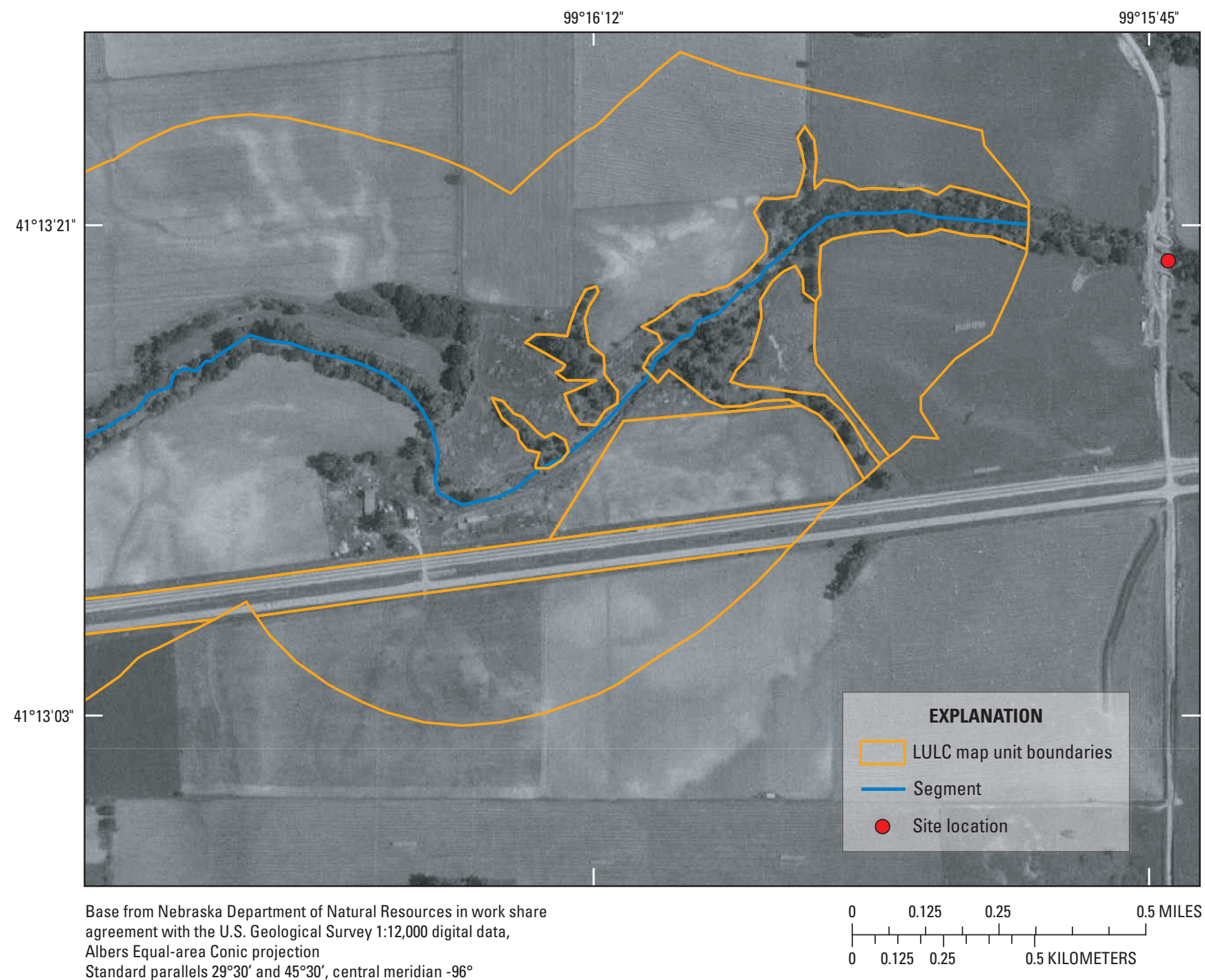

Figure 3. Addition of land-use/land-cover (LULC) map unit boundaries to subdivide the LULC_S250 coverage into LULC categories for Mud Creek near Mason City, Nebraska. 


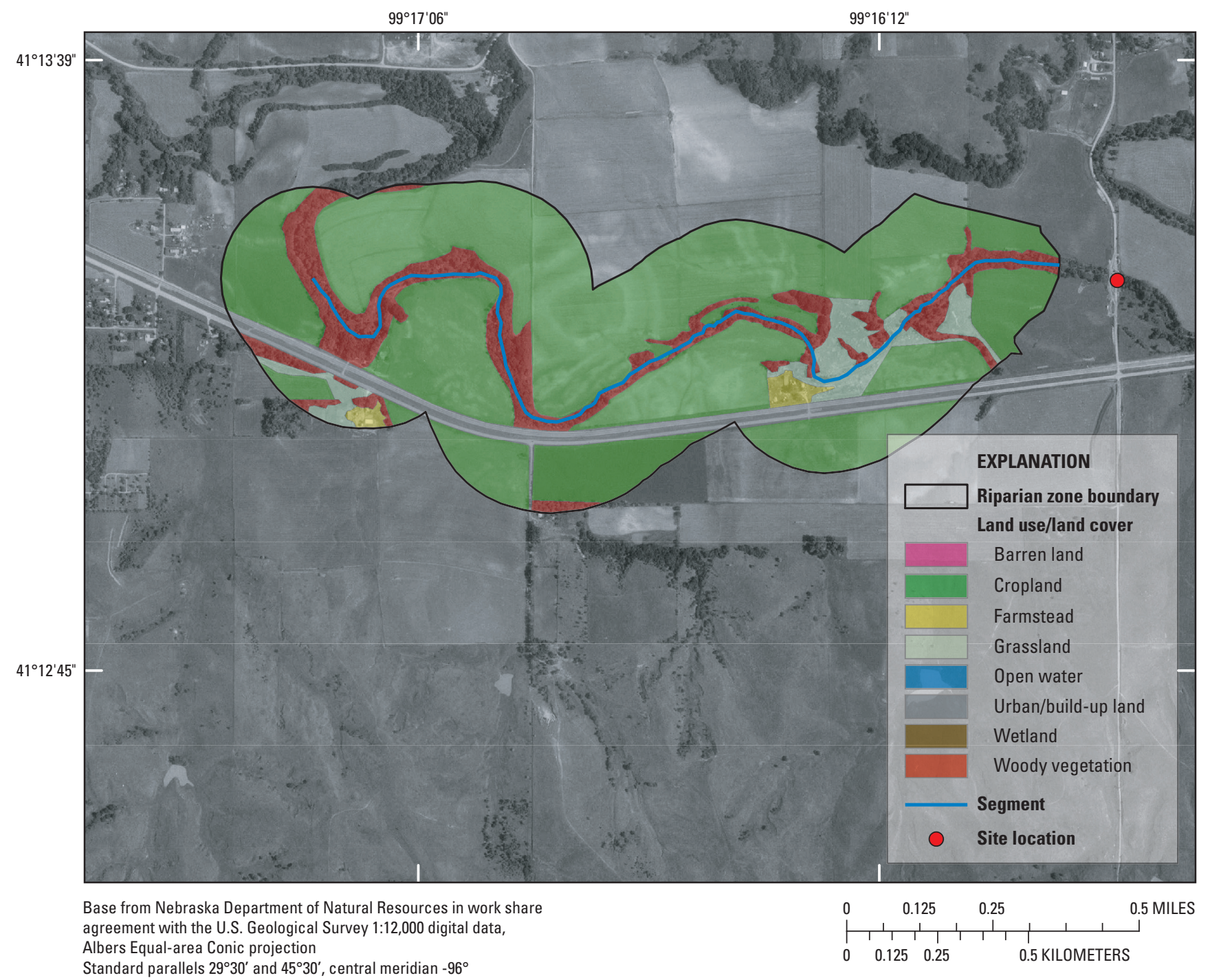

Figure 4. Mapped and classified land use/land cover within the riparian zone along a stream segment for Mud Creek near Mason City, Nebraska. 


\section{Stream Margin Land Use/Land Cover within Riparian Habitat Inventory Zone}

The relative linear extent of each LULC type and frequency of gaps in the riparian woodland corridor along the stream can be quantified efficiently once a stream centerline (SEGMENT) has been digitized. Longitudinal riparian transect lines parallel to, but offset from, the centerline are generated by buffering the stream SEGMENT coverage based on the offset width and extracting the line segments sampling the left and right banks. The offset width is calculated from the mean bankfull width, as follows. For each segment, mean bankfull width can be assumed equivalent to the reach-level bankfull width, $W_{b f}$ The total offset distance $\left(W_{o f f}\right)$, in meters, is calculated as:

$$
W_{o f f}=\left[\left(0.5 \times W_{b f}\right)+15\right]
$$

so that the longitudinal transect lines bisect the reach-level riparian habitat zone, defined for NAWQA sampling as a 30-m width beyond the top of each bank (Fitzpatrick and others, 1998).

The offset width is added as an attribute column, WIDTH, to the SEGMENT data table. The buffer function generates longitudinal transect lines, using the attribute, WIDTH, as the buffer distance. The segment-buffered output boundary coverage, SMARGIN_BUF, is copied to a new coverage,

SMARGIN_LINE, with linear-feature topology calculated using the build function. The SMARGIN_LINE lines need to be edited to delete the rounded arcs around the beginning and ending parts of the stream segment, or "end caps," leaving only the desired transect lines (fig. 5).

Then, an overlay analysis is performed, whereby the longitudinal transect lines (SMARGIN_LINE) are tested for geometric intersection (intersect function) with the LULC

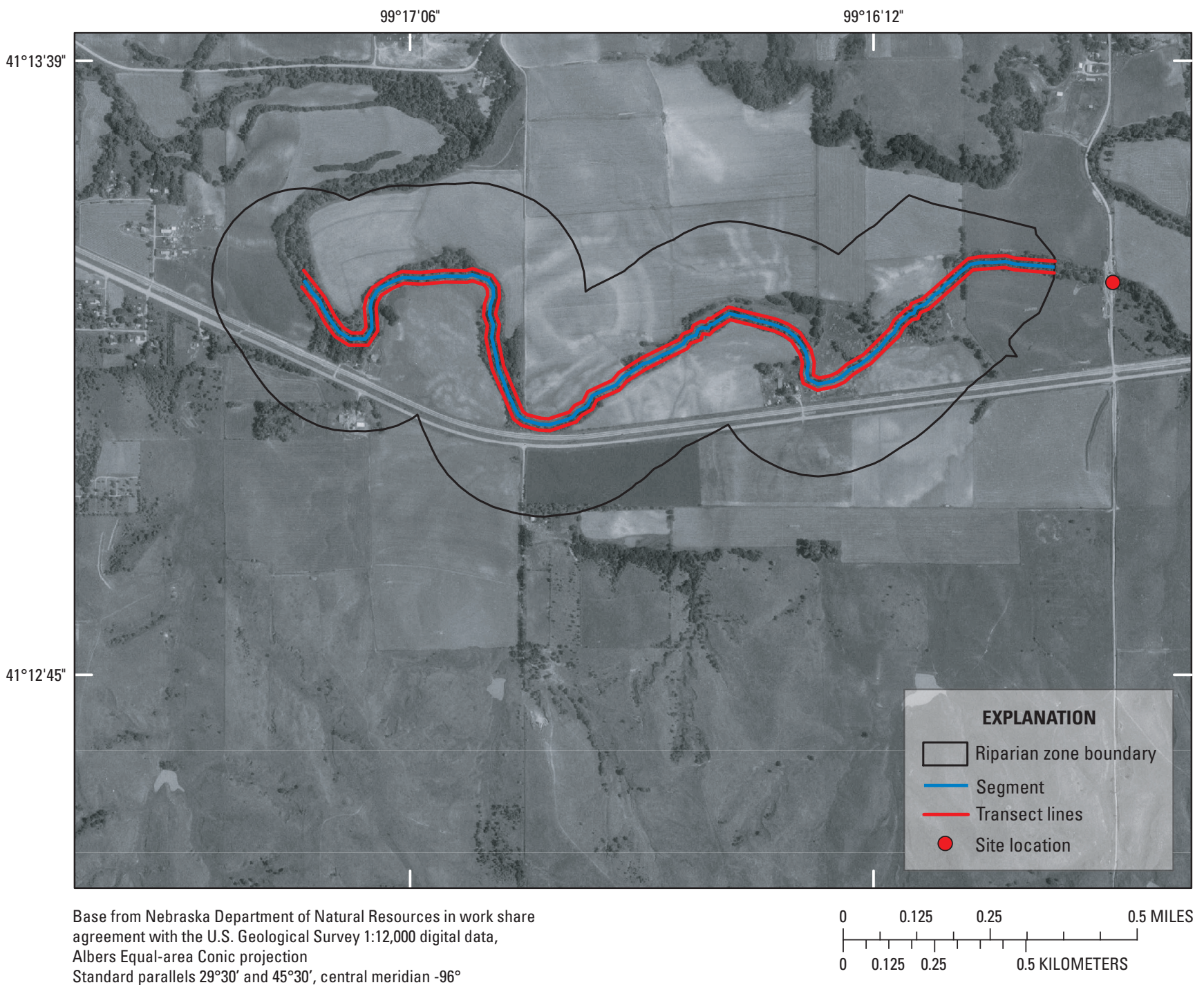

Figure 5. Stream margin lines are generated by buffering the blue centerline and deleting the "end caps" leaving only the red transect lines. 
map units within the riparian zone, LULC_S250. The product of this intersection, S_MARGIN, would encode the type and sequence of land cover(s) that typifies the riparian zone along that stream segment (fig. 6). The same process would be repeated to create the stream margin habitat at the reach scale.

Because the land cover types have been assigned, the lengths of stream bordered by each category of riparian zone are readily tabulated using GIS processing. The overlay process results in a coverage of longitudinal line segments by LULC types and these can be characterized in various ways. For instance, the categorized lengths may be expressed as percentages of stream length overall. Mean gap length of non-woody vegetation map units also can be obtained by calculating the mean arc length for each non-woody vegetation LULC type (Schuft and others, 1999). Frequency of gaps can be calculated as the number of gaps between woody vegetation map units per kilometers of stream length.
Additional processing steps need to be performed to calculate statistics on the frequency of gaps and mean gap length. The S_MARGIN and R_MARGIN coverages should be copied to new coverages, S_FREQ and R_FREQ, respectively. A new binary attribute, GAP, should be added to the table. The field can be of character type with length 2 and coded " $n$ " if the LULC type is either woody vegetation, "WV," or shrubland, "S," and coded " $y$ " if the type is anything else. The multiple adjoining arcs that are non-woody vegetation, or with a GAP value of "y," need to be combined or unsplit. Edit each coverage in ArcEdit and run unsplit on the arcs coded, GAP = "y." These arcs should be populated with the STAID. Then statistics (mean gap length and frequency of gaps) on riparian woodland gaps can be calculated for each site.

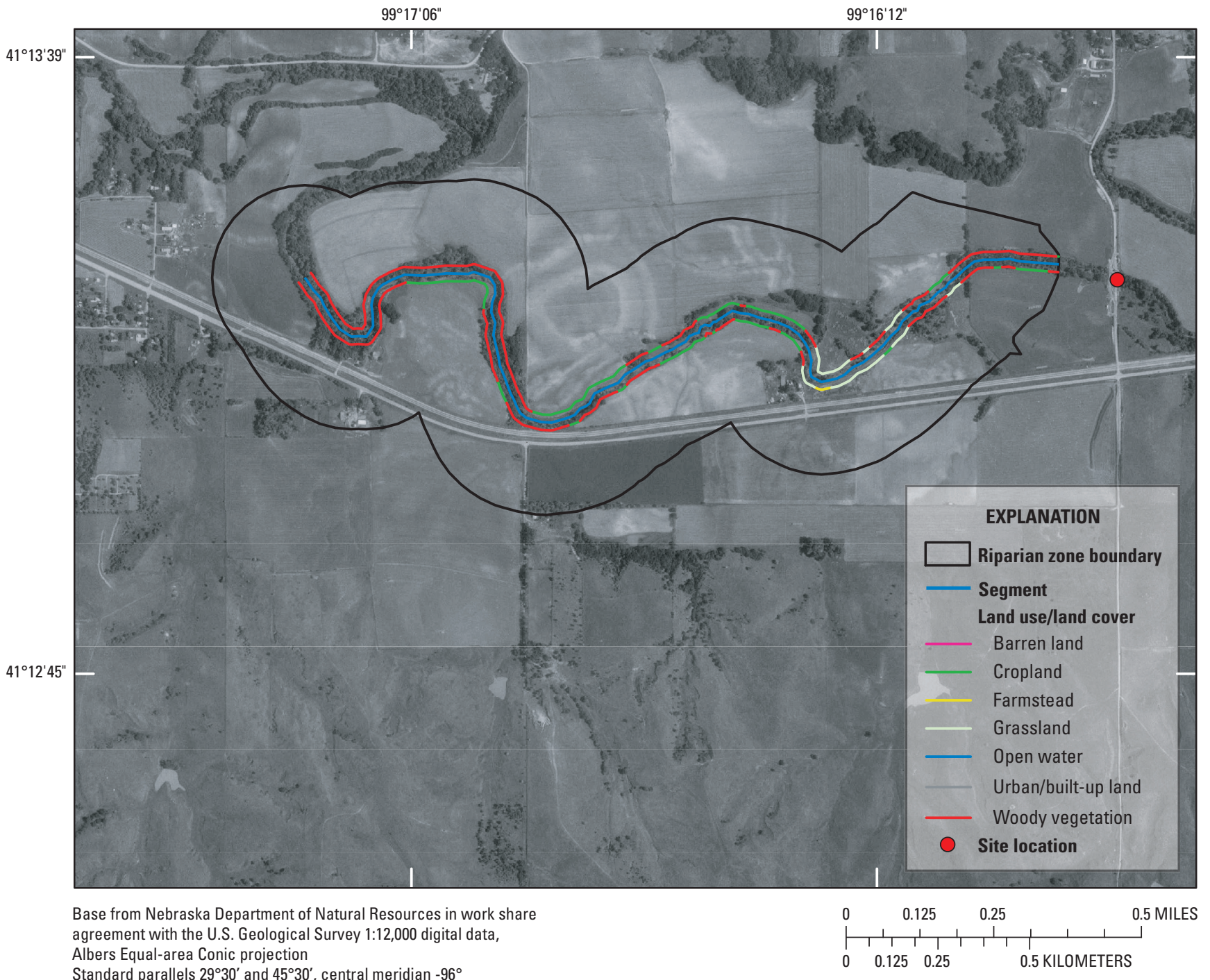

Figure 6. Results of sampling the land cover along the longitudinal bisectors of the NAWQA-defined riparian habitat inventory zone of $30 \mathrm{~m}$ beyond each stream bank. 


\section{Accuracy Assessment of Land-Use/Land-Cover Mapping}

An accuracy assessment was not conducted for this study because ground-truth data were not collected at the time of sampling, nor was the date of aerial photo acquisition concurrent with field sampling. Future studies could benefit from implementation of the protocol in advance of field activity, and collection of ground-truth LULC data concurrent with field sampling, for example, by using global positioning system (GPS) receivers during site visits to document the land cover in each type of mapping unit. Also, airborne imagery (for example, IKONOS), or other near-infrared or multispectral imagery ideally would be used as source materials. This was not feasible for the CNBR study because of a combination of imagery availability, cost, and time constraints.

\section{Characterizing Land Use/Land Cover in the Riparian Zone}

The protocol was used by the CNBR Study Unit to characterize LULC in the riparian zone. The results of the characterization for the CNBR Study Unit are presented in this section as an example. The 28 sampling sites in the CNBR Study Unit are shown in figure 7.

\section{Relative Areal Extent of Land Use/Land Cover Types}

The results for the CNBR Study Unit at the segment level showed that the relative dominance of woody vegetation in the riparian zone decreased as the buffer width (lateral extent) increased (table 2). The sites represented an intensively cultivated landscape because about 25 to 54 percent of the riparian zone at the segment level was covered by cropland. The results for the 28 sampling sites in the CNBR Study Unit at the reach level indicated that riparian areas were primarily grassland and woody vegetation (table 2).

\section{Linear Extent of Land Use/Land Cover Types and Frequency of Gaps of Non-Woody Vegetation}

The LULC at the segment level from LULC sampling along the longitudinal transects bisecting the riparian habitat inventory zones showed grassland and woody vegetation as the dominant LULC types (table 3). The frequency of gaps in the riparian woodland corridor ranged from 0.49 to 7.10 per $\mathrm{km}$ of stream length. Mean gap length was $229 \mathrm{~m}$, and ranged from 1 to $3,103 \mathrm{~m}$ for the 28 stream segments.

The LULC for the longitudinal transects at the reach level was predominantly grassland and woody vegetation (table 3 ). The frequency of gaps at the reach level ranged from 0 to 17.1 per $\mathrm{km}$ of stream length. Mean gap length was $92 \mathrm{~m}$, and ranged from 1 to $328 \mathrm{~m}$.

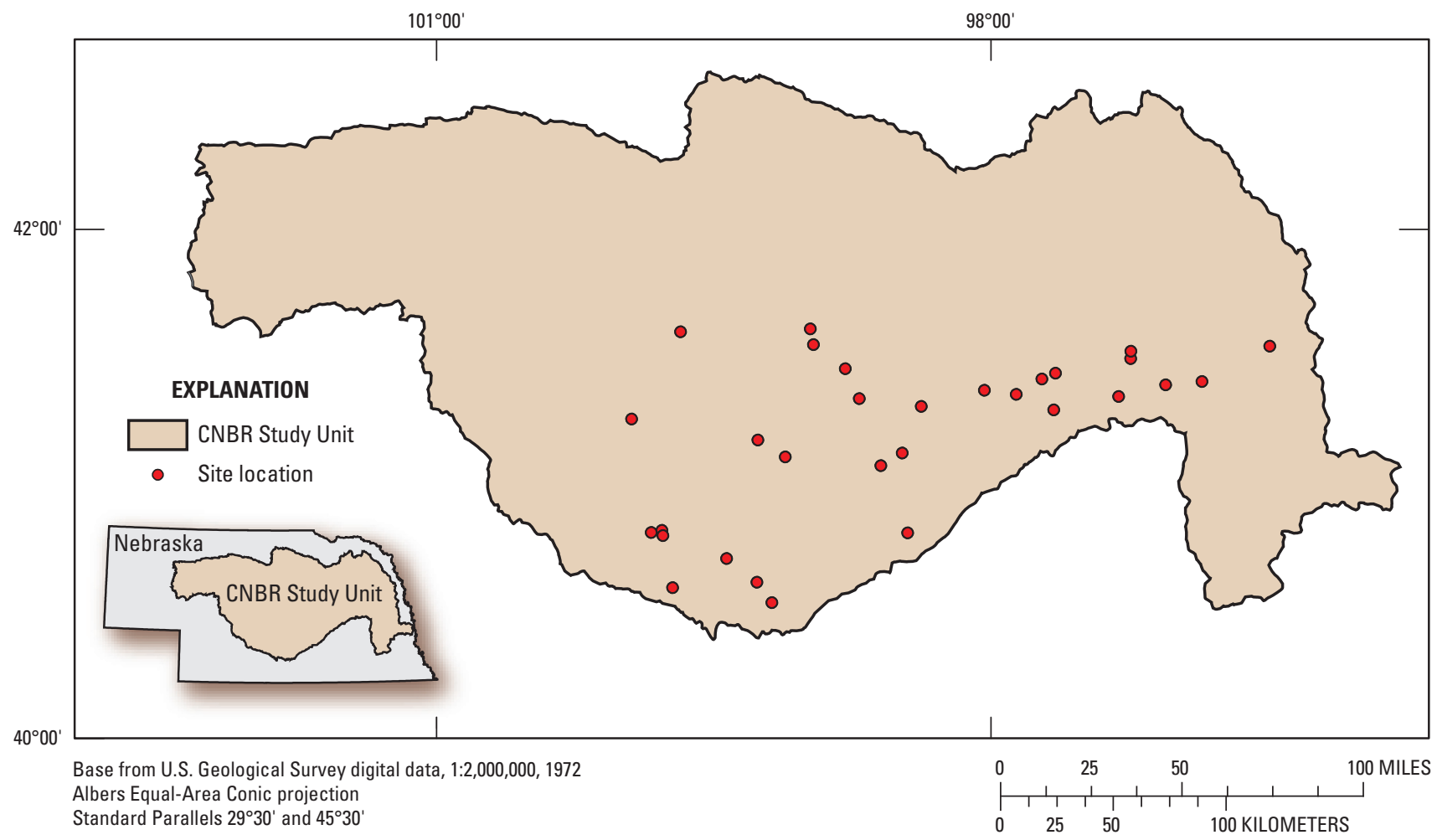

Figure 7. Location of the 28 sampling sites in the Central Nebraska Basins (CNBR) Study Unit. 
Table 2. Relative areal extent of each land use/land cover class.

[Units are all in percent; $\mathrm{m}$, meter; $<$, less than]

\begin{tabular}{rcccccccc}
\hline $\begin{array}{c}\text { Lateral } \\
\text { extent }(\mathbf{m})\end{array}$ & $\begin{array}{c}\text { Barren } \\
\text { land }\end{array}$ & Cropland & Farmstead & Grassland & $\begin{array}{c}\text { Open } \\
\text { water }\end{array}$ & $\begin{array}{c}\text { Urban/ } \\
\text { built-up land }\end{array}$ & Wetland & $\begin{array}{c}\text { Woody } \\
\text { vegetation }\end{array}$ \\
\hline & & & & \multicolumn{2}{c}{ Segment level } \\
50 & 2 & 25 & $<1$ & 38 & 4 & $<1$ & 0 & 30 \\
100 & 1 & 39 & $<1$ & 34 & 2 & 1 & 0 & 22 \\
150 & $<1$ & 47 & $<1$ & 30 & 2 & 1 & $<1$ & 18 \\
250 & $<1$ & 54 & $<1$ & 27 & 1 & 1 & $<1$ & 15 \\
& & & & Reach level & & & \\
25 & $<1$ & 10 & $<1$ & 36 & 10 & $<1$ & 0 & 43 \\
50 & $<1$ & 25 & $<1$ & 36 & 5 & $<1$ & 0 & 32 \\
\hline
\end{tabular}

Table 3. Linear extent of each land use/land cover class along longitudinal transects of stream segments and reaches.

[Units are all in percent; <, less than]

\begin{tabular}{cccccccc}
\hline Barren land & Cropland & Farmstead & Grassland & $\begin{array}{c}\text { Open } \\
\text { water }\end{array}$ & $\begin{array}{c}\text { Urban/ } \\
\text { built-up land }\end{array}$ & Wetland & $\begin{array}{c}\text { Woody } \\
\text { vegetation }\end{array}$ \\
\hline 2 & & & & Segment level & & & \\
\hline$<1$ & 25 & $<1$ & 40 & $<1$ & $<1$ & 0 & 32 \\
\hline
\end{tabular}

\section{Summary}

The purpose of this report is to outline the protocols used to map and characterize riparian zones of streams at both the segment and reach scales. The protocols are documented for use by the U.S. Geological Survey's National Water-Quality Assessment (NAWQA) Program. This report describes a method for filling in a data gap of spatial scale in woodland land use/land cover (LULC) between the 30-m land-cover data available from the 1990s National Land Cover Dataset and the reach-level data available from the prescribed NAWQA habitat assessment. Characterization of riparian systems is critical to a comprehensive understanding of nutrient enrichment effects on stream ecosystems. The protocol is documented to standardize the approach so that resulting data are comparable among different sites analyzed and across different time periods. This method is cost-effective, and the resulting riparian LULC include those data at the ecologically important scale of stream segments. The process examines LULC along a stream centerline segment, the length of which is determined from the logarithm of the basin area. The riparian zone is operationally defined by the maximum buffer width, $250 \mathrm{~m}$, extending outward from the stream centerline. Delineation of LULC map units is performed using on-screen digitizing of riparian LULC classes from digital orthophoto quarter-quadrangles. The riparian LULC units are mapped using a classification strategy consisting of nine classes. Longitudinal riparian transect lines, parallel to but offset from the centerline, are generated and partitioned into the underlying LULC types to obtain the relative linear extent of LULC types and frequency of non-woody vegetation, or gaps, along the stream within the riparian zone. This protocol was followed for NAWQA's Central Nebraska Basins Study Unit. The results of characterizing the riparian zone in this Study Unit showed that cropland was the dominant LULC type in areal extent, and woody vegetation and grasses were the dominant linear features. 


\section{References Cited}

Anderson, J.R., Hardy, E.E., Roach, J.T., and Witmer, R.E., 1976, A land use and land cover classification system for use with remote sensor data: U.S. Geological Survey Professional Paper 964, 28 p.

Banerjee, Neal, 2002, Shorten arc user-specified distance in either direction (ashorten.aml): Redlands, Calif., ESRI, accessed February 2, 2005, at http://arcscripts.esri.com/ details. asp ? dbid $=12077$

Brinson, M.M., Swift, B.L., Plantico, R.C., and Barclay, J.S., 1981, Riparian ecosystems - Their ecology and status: Washington, D.C., Office of Biological Services, U.S. Fish and Wildlife Service, FWS/OBS-81/17, 154 p.

Fitzpatrick, F.A., Waite, I.A., D'Arconte, Meador, M.R., Maupin, M.A., and Gurtz, M.E., 1998, Revised methods for characterizing stream habitat in the National Water-Quality Assessment Program: U.S. Geological Survey WaterResources Investigations Report 98-4052, 67 p.

Fitzpatrick, F.A., Scudder, B.C., Lenz, B.N., and Sullivan, D.J., 2001, Effects of multi-scale environmental characteristics on agricultural stream biota in eastern Wisconsin: Journal of the American Water Resources Association, v. 37, p. 1489-1507.

Frissell, C.A., Liss, W.J., Warren, C.E., and Hurley, M.D., 1986, A hierarchical framework for stream habitat classification-Viewing streams in a watershed context: Environmental Management, v. 10, p. 199-214.

Gregory, S.V., Swanson, F.J., McKee, W.A., Cummins, K.W., 1991, An ecosystem perspective of riparian zones: BioScience, v. 41, p. 540-551.

Lattin, P.D., Wigington, P.J., Moser, T.J., Jr., Peniston, B.E., Lindeman, D.R., and Oetter, D.R., 2004, Influence of remote sensing imagery source on quantification of riparian land cover/land use: Journal of the American Water Resources Association, v. 40, p. 215-227.
Lillesand, T.M., and Kieffer, R.W., 1994, Remote sensing and image interpretation, ( $3 \mathrm{~d}$ ed.): New York, John Wiley and Sons, $750 \mathrm{p}$.

Malanson, G.P., 1993, Riparian landscapes: United Kingdom, Cambridge University Press, 296 p.

Naiman, R.J., 1992, New perspectives for watershed management, in R.J. Naiman, (ed.), Watershed managementbalancing sustainability and environmental change: New York, Springer-Verlag, p. 3-11.

Schuft, J.S., Moser, T.J., Wigington, P.J. Jr., Stevens, D.L. Jr., McAllister, L.S., Chapman, S.S., and Ernst, T.L., 1999, Development of landscape metrics for characterizing riparian-stream networks: Photogrammetric Engineering and Remote Sensing, v. 65, no. 10, p. 1157-1167.

Sorenson, S.K., Porter, S.D., Akers, K.K.B., Harris, M.A., Kalkhoff, S.J., Lee, K.E., Roberts, L.R., and Terrio, P.J., 1999, Water quality and habitat conditions in Upper Midwest streams relative to riparian vegetation and soil characteristics, August, 1997-Study design, methods, and data: U.S. Geological Survey Open-File Report 99-202, $53 \mathrm{p}$.

Sponseller R.A., Benfield, E.F., Valett, H.M., 2001, Relationships between land use, spatial scale and stream macroinvertebrate communities: Freshwater Biology, v. 46, p. 1409-24.

Stauffer, J.C., Goldstein, R.M., and Newman, R.M., 2000, Relationship of wooded riparian zones and runoff potential to fish community composition in agricultural streams: Canadian Journal of Fisheries and Aquatic Sciences, v. 57, p. 307-316.

U.S. Geological Survey, 1998, Ditigal orthophoto quadrangles: U.S. Geological Survey Fact Sheet FS-129-95, 2 p.

Vogelmann, J.E., Howard, S.M., Yang, L., Larson, C.R., Wylie, B.K., and Van Driel, N., 2001, Completion of the 1990's national land cover dataset for the conterminous United States from Landsat Thematic Mapper data and ancillary data sources: Photogrammetric Engineering and Remote Sensing, v. 67, p. 650-662. 


\section{Protocols for Mapping and Characterizing Land Use/Land Cover in Riparian Zones}

\section{Appendix}

Source code for the Arc Macro Language (AML) program ashorten.am/ follows:

/* ashorten.aml

/* AML to shorten an arc a user specified distance.

/* Descp: This AML will shorten the selected arc a user-specified distance. The AML

/* will split the line based on the distance entered, and then delete the

/* segment with the user specified distance. The user can use 'oops' to

/* return to the original line, or the split line. This AML is meant to be

/* run from the ARCEDIT prompt. It is suggested that you put this file in

/* the \$ARCHOME\atool \arcedit directory so that you can use it as you would

/* use any other ARCEDIT command (i.e. without typing \&r)

/* Notes: To shorten from the end of the line, type a positive distance. To

/* shorten the arc from the beginning of the line, type a negative distance.

/* Required Support Files: none

/* Acknowlegements: Thanks to Bob Hyatt (author of measure.aml). I used a version of his line measureing algorithm in this AML.

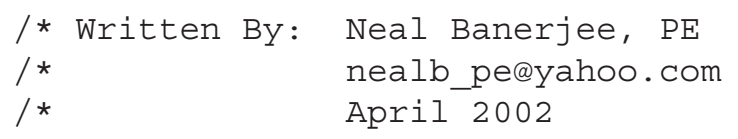

\&severity \&warning \&ignore

\&severity \&error \&ignore

\&echo \&off

/* Default distance to shorten from end of line \&args shrtdist

/* Display usage if invalid

\&if [null \%shrtdist\%] or [type \%shrtdist\%] > 0 \&then

\&do

de arc arrow

drawsel

de arc

\&type Usage: ashorten <shrtdist>

\&s shrtdist $=$ [response 'Enter distance to shorten selected arc' 0]

\&end

/ * VALIDITY CHECKS

/* Arc topology and number of selected items check

\&if [show ef] $<>$ ARC or [show number select] $<1$ \&then

\&stop ERROR: Edit feature must be ARC and one feature must be selected.

/* Arc length vs. shorten distance check

\&s arcid = [show select 1] /* Get ID of selected arc

\&S arc_length $=$ [show arc oarcid\% item length] /* Determine length of arc

\&if \%arc_length\% < [abs \%shrtdist\%] \&then

\&do 


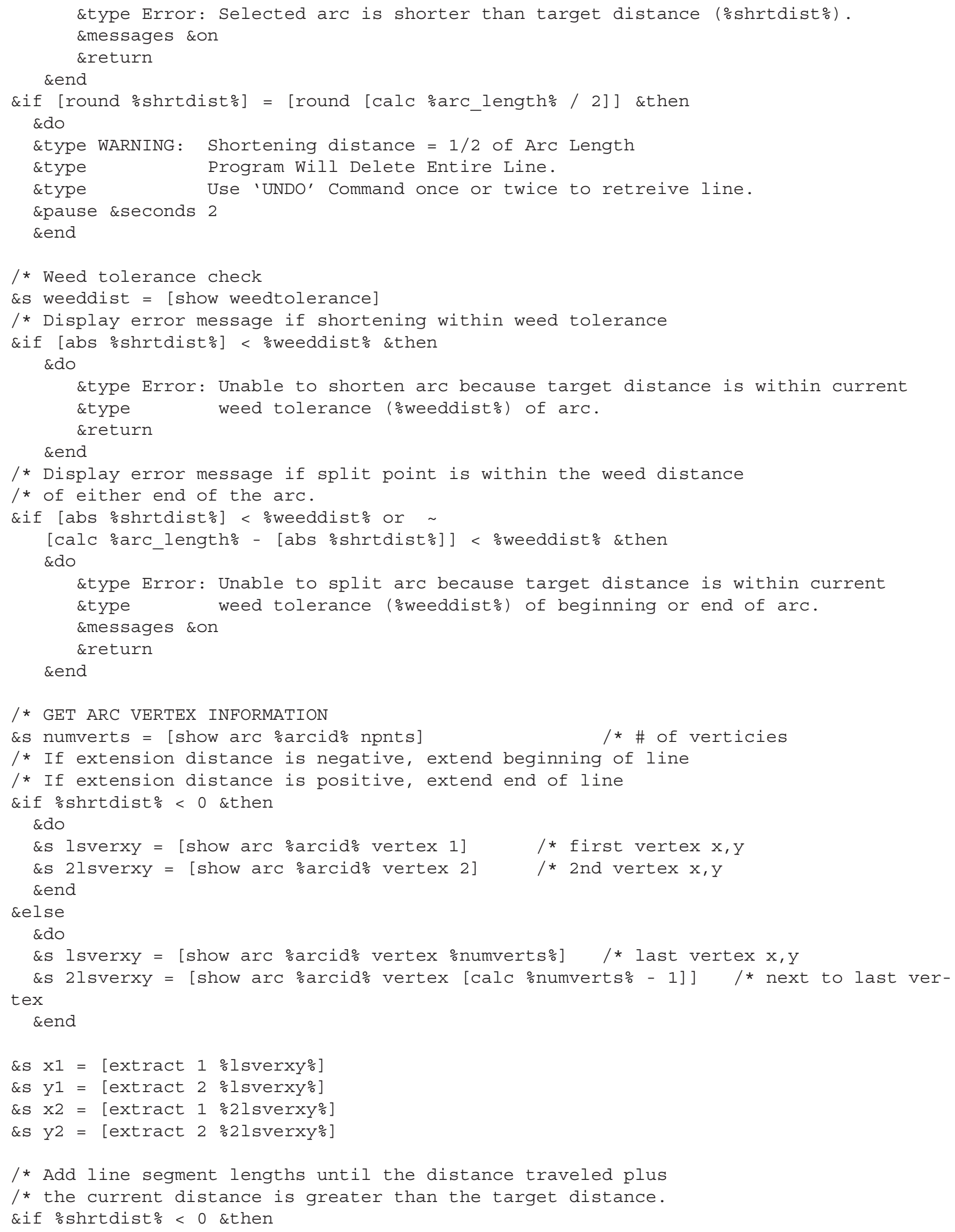




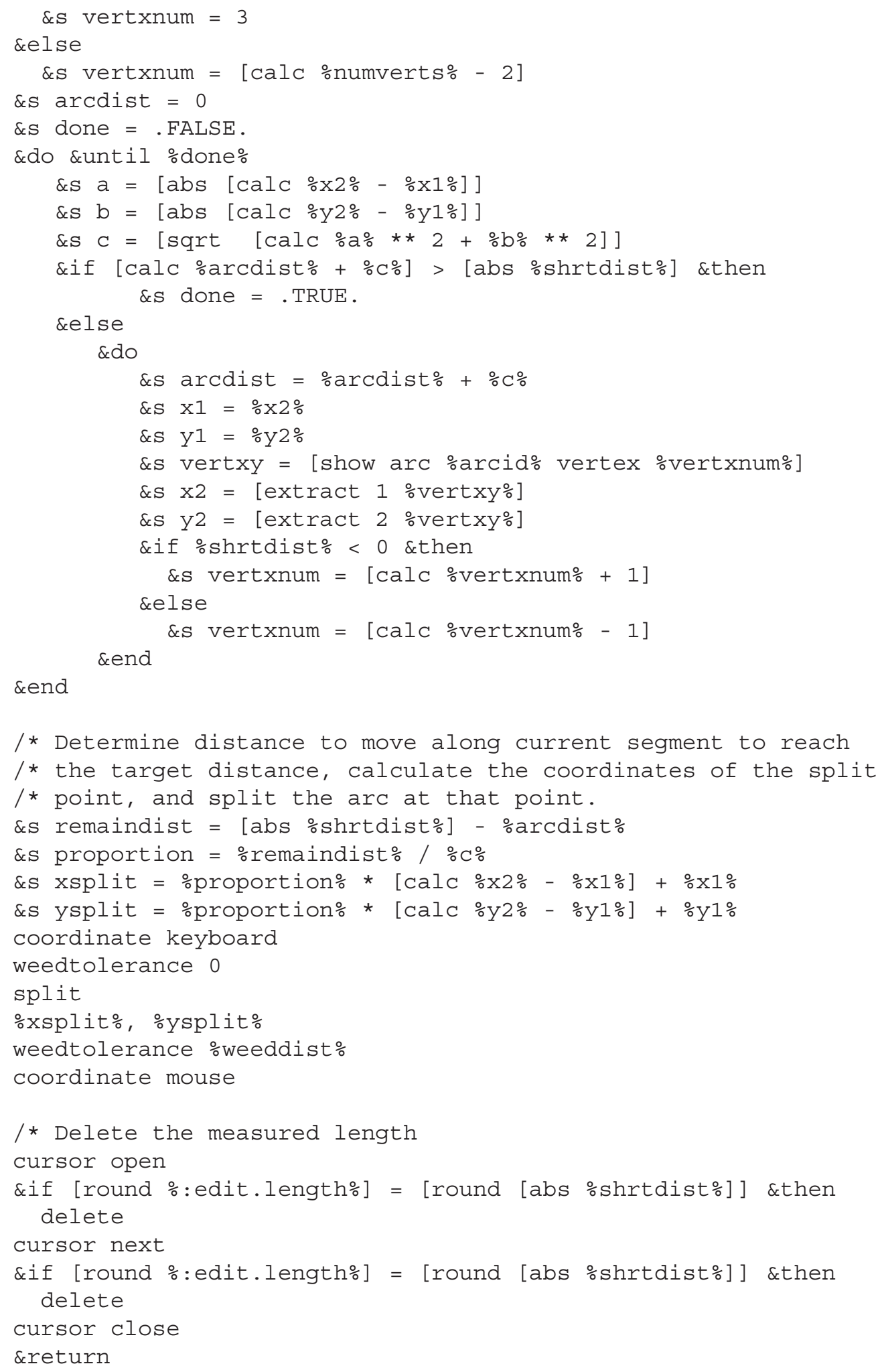





$$
\text { 焉 }
$$

